http://dx.doi.org/10.15407/ukrbotj72.04.310

\title{
Л.М. МАХИНЯ
}

Національний медичний університет імені О.О. Богомольця

вул. Пушкінська, 22, м. Київ, 01601, Україна

Larisa_2015@ukr.net

\section{СИНТАКСОНОМІЯ КЛАСУ ВIDENTETEA TRIPARTITAE ДОЛИНИ ДНІПРА (В МЕЖАХ ЛІСОСТЕПУ УКРАЇНИ)}

\begin{abstract}
Махиня Л.М. Синтаксономія класу Bidentetea tripartitae долини Дніпра (в межах Лісостепу України). - Укр. ботан. журн. - 2015. - 72(4): 310-324.

У статті наведена синтаксономія класу Bidentetea tripartitae Tüxen et al. ex von Rochow 1951 здолини Дніпра, яка має шість асоціацій, що належать до двох союзів (Bidention tripartitae Nordhagen ex Klika et Hadač 1940 i Chenopodion rubri (Tüxen 1960) Hilbig et Jage 1972) та одного порядку - Bidentetalia tripartitae Br.-Bl. et R. Tx. ex Klika et Hadač 1944. Основними факторами, котрі обумовлюють їхній розподіл у долині, є відмінності рельєфу, грунтового покриву та гідрологічного режиму. Флористичний склад налічує 138 видів, які належать до 105 родів і 43 родин. Діагностичними видами класу є Lythrum salicaria L., Rorippa palustris (L.) Besser, Bidens cernua L., B. frondosa L., B. tripartita L., Polygonum hydropiper L., P. persicaria L. Високою константністю відзначаються Bidens frondosa, B. tripartita, Polygonum hydropiper. Середній рівень константності характерний для Bidens cernua, B. connata Muhl. ex Willd. та Juncus bufonius L. Найнижчий - властивий Myosoton aquaticum (L.) Moench і діагностичним видам інших класів, зокрема Potentilla anserina L. (Plantaginetea majoris), Lycopus europaeus L. (Phragmito-Magno-Caricetea), Agrostis canina L. (MolinioArrhenatheretea), Atriplex prostrata DC. (Stellarietea mediae).
\end{abstract}

К л ю ч о в і с л о в а: синтаксономія, еколого-ценотична характеристика, прибережно-водна рослинність, долина Дніпра, Bidentetea tripartitae

Угруповання класу Bidentetea tripartitae Tüxen et al. ex von Rochow 1951 відіграють важливу роль у відтворенні порушених екосистем і здійснюють прямий або опосередкований вплив на формування прибережної природної рослинності. Вони мають високу постійність флористичного складу, що зумовлено впливом водного середовища, яке створює оптимальні, але водночас специфічні, внаслідок коливання рівня води, умови для розвитку однорічних терофітів. Їхні угруповання часто $\epsilon$ пусковим механізмом майбутніх сукцесійних процесів, які визначають динаміку рослинності та ресурсний потенціал місцезростань.

Для виявлення цього потенціалу, а також з'ясування існуючих і прогнозованих майбутніх змін у ценозах важливою є еколого-ценотична характеристика угруповань досліджуваного класу. Досі вона залишалася маловивченою.

\section{Об’єкти та методи досліджень}

Назви видів подано відповідно до «Определителя ..., 1999» (Opredelitel vysshikh rasteniy Ukrainy, 1999).

Еколого-ценотичні дослідження ми проводили протягом 2004-2014 pр. з використанням традиційних геоботанічних методів (Barkman, 1989; ( ) Л.М. МАХИНЯ, 2015
Mirkin et al., 2002). Маршрутним способом охопили основні місцезростання видів у межах долини вздовж правого та лівого берегів Дніпра, починаючи від м. Києва до м. Кременчука (Полтавська обл.). Збір польових даних та їхню камеральну обробку виконували за методом Браун-Бланке (Braun-Blanquet, 1964). Здійснили 300 геоботанічних описів. Впорядкування геоботанічного матеріалу проводилося шляхом створення бази даних у форматі TURBOVEG 2.79 (Hennekens, Schaminée, 2001) та їх обробки з використанням програмного пакету JUICE 7.0.83 (Tichý, 2002). Діагностичні види синтаксонів визначали відповідно до значень коефіцієнта phi (Willner et al., 2002). Назви синтаксонів наведені згідно з правилами третього видання Міжнародного кодексу фітосоціологічної номенклатури (ICPN) (Weber, Moravec, Theurillat, 2000).

\section{Результати досліджень і їх обговорення}

Ценофлора класу Bidentetea tripartitae налічує 138 видів, які належать до 105 родів і 43 родин. У інших авторів клас характеризується меншим флористичним складом, який коливається у межах від 22 до 97 видів, а також родинним багатством - від 10 до 20 родин (Levon, 1996; Osypenko, Shevchyk, 2001; Dubyna et al., 2002). Найбільшою кількістю 
серед представників ценофлори класу щодо різних трофічних елементів грунту відзначалися гемікарбонатофоби (62\%), семіевтрофи (56\%), субацидофіли (54 \%) та нітрофіли (51 \%). Середня кількість нейтрофілів - $36 \%$, гемінітрофілів - $33 \%$, евтрофів - $29 \%$, акарбонатофілів - $28 \%$. Найменше виявлено еунітрофілів (10\%), мезотрофів (10\%), ацидофілів (9\%), карбонатофобів (7 \%), субанітрофілів (5\%), субглікотрофів (4 \%) та гемікарбонатофілів (3 \%). Поодиноко трапляються перацидофіли (1\%), семіоліготрофи (1\%) та мезофіли (1\%).

Щодо географічного спектра флори, то більша кількість представників класу належить до плюризональної (30 \%), борео-меридіональної (27 \%), борео-субмеридіональної (17 \%) зональних хорологічних груп, меншу кількість видів мають температно-меридіональна (10\%), температно-субмеридіональна (9 \%), субмеридіональна (3,6 \%) і арктосубмеридіональна $(1,4 \%)$ групи, найменшу - аркто-меридіональна (1\%) та борео-температна (1\%) групи.

Представники класу належать переважно до циркумполярної (32\%), гемікосмополітної (22 \%) та євро-азійської груп (16 \%). Окремі види відносяться до євро-північноамериканської (6,1%), європейської (6 \%), космополітної (6\%), древньосередземноморської (5,5\%), євро-сибірської (2\%), причорноморської (1,5 \%), євро-західносибірської $(1,5 \%)$, європейсько-середземноморської $(1,4 \%)$ хорологічних груп.

За градієнтом океанічності-континентальності більшість видів класу є індиферентними (80 \%) й лише окремі - евриконтинентальними (8 \%), евриокеанічними (7 \%) та евконтинентальними (5\%).

Синтаксономічна схема Bidentetea tripartitae долини Середнього Дніпра (в межах Лісостепу України)

Bidentetea tripartitae Tüxen et al. ex von Rochow 1951

Bidentetalia tripartitae Br.-Bl. et R. Tx. ex Klika et Hadač 1944

Bidention tripartitae Nordhagen ex Klika et Hadač 1940

Bidentetum frondoso-connatae ass. nova hoc. loco Junco bufonii-Bidentetum connatae (Timmermann 1993) Passarge 1996

Bidentetum tripartitae Miljan 1933

Bidenti tripartitae-Polygonetum hydropiperis (Miljan 1933) Lohmeyer in R. Tx. 1950
Bidentetum cernuae Slavnić 1951

Chenopodion rubri (Tüxen 1960) Hilbig et Jage 1972

Bidenti frondosae-Atriplicetum prostratae Poli et J. Tüxen 1960 corr. Gutermann et Mucina 1993.

Клас Bidentetea tripartitae об'єднує угруповання гігрофітів, що формуються на нітрифікованих або слабонітрифікованих, перезволожених і сирих місцезростаннях по берегах річок, поблизу водостічних канав, на прибережних частинах боліт, а також на пониженнях грунтів, що періодично затоплюються. Особливістю класу є висока постійність флористичного складу. А.Р. Ішбірдін зі співавторами пояснюють це стабілізуючою дією водного середовища (Ishbirdin et al., 2005). Клас включає один порядок (Bidentetalia tripartitae) та два союзи - Bidention tripartitae i Chenopodion rubri. Дiагностичними видами класу є Lythrum salicaria L., Rorippa palustris (L.) Besser, Bidens cernua L., B. frondosa L., B. tripartita L., Polygonum hydropiper L. i P. persicaria L.

Площі угруповань синтаксону від 2004 по 2014 р. мають тенденцію до скорочення. Провідними факторами загроз є забруднення за участю $B$. frondosa, а також зміна гідрорежиму та руйнування прибережних ділянок. У верхній частині долини Дніпра відзначаються найменші масиви угруповань, чому сприяє також посилений антропогенний тиск (одамбування, ставкобудівництво, штучне затоплення, забудова прибережних територій). Середня та нижня частини Дніпра характеризуються масивами угруповань, приурочених до заплавних ділянок приток Дніпра (річки Тясмин, Супой, Рось, Золотоношка, Кропивна). У нижній частині його долини угруповання займають найбільші площі, на що впливає наявність островів (Динька, Калантаїв, Шаламай, Стрілецький та ін.).

Порядок Bidentetalia tripartitae має два союзи й об'єднує угруповання прибережних ділянок водойм, а також заболочених місцезростань і новоутворених ділянок мілководдя. Діагностичні види порядку відповідають діагностичним видам класу.

Союз Bidention tripartitae включає ценози середньовисокотравних повітряно-водних видів, прісноводних, слабо- проточних або непроточних водойм із помірним коливанням рівня води під час вегетації та прибережних ділянок, які в літньо-осінній період залишаються без поверхневого підтоплення. Він налічує вісім асоціацій. Діаг- 
ностичними видами союзу є Bidens cernua, Lycopus europaeus L. i Polygonum hydropiper.

Союз Chenopodion rubri об'єднує угруповання, приурочені до берегів водойм із наносними піщаними грунтами. Має одну асоціацію. Його діагностичними видами є Chenopodium album L. i Ch. rubrum L.

Асоціація Bidentetum frondoso-connatae ass. nova hoc. loco (табл. 1). Діагностичними видами є Bidens frondosa i B. connata.

Номенклатурний тип (holotypus): опис №6 (табл. 1) Київська обл., Бориспільський р-н, с. Проців, прибережна ділянка оз. Кошарище $\left(50^{\circ} 1408^{\prime \prime}\right.$ п. ш. $30^{\circ} 4710^{\prime \prime}$ с. д.), 15.09.2006. Л.М. Махиня.

Ценотична характеристика: загальне проективне покриття травостою 80-100\%; B. frondosa 70-80\%, B. connata - 50-55\%, J. bufonius 1-5\%. Склад флори відзначається середнім видовим багатством і налічує 53 види. Для нього характерні переважно представники класу Bidentetea tripartitae, трапляються діагностичні види класів Alnetea glutinosae (Alnus glutinosa Gaertn.), PhragmitoMagno-Caricetea (Lycopus europaeus). Кількість видів у описах коливається в межах 8-13.

Синекологія: угруповання приурочені до ділянок, що мають змінний гідрорежим під час вегетації з мулисто-піщаними слабозадернованими грунтами. Характерні для прибережних ділянок малих річок (Павлівка, Ірдинка), озер (Баклажанне), штучних водойм, каналів, кар'єрів торфорозробок (Ірдинські болота), заплавних лісів (угруповання 3 A. glutinosa) та ділянок болотистих лук.

Синморфологія: угруповання двопід'ярусні, їх утворюють види $з$ широкою екологічною амплітудою. Перший під'ярус (50-120 см) формують Bidens cernua, B. connata, B. frondosa, Polygonum hydropiper, Lycopus europaeus, Leersia oryzoides (L.) Sw., Chenopodium album L., Mentha spicata L., Equisetum sylvaticum L.; другий (10-45 см) формують Carex acuta L., Plantago major L., Juncus bufonius. Ценози мають вигляд окремих локалітетів.

Синдинаміка: започатковують еколого-ценотичні ряди прибережно-водної рослинності, їх змінюють угруповання лучної (Molinio-Arrhenatheretea), рідше - рудеральної (Stellarietea mediae, Plantagineta majoris) рослинності.

Синхорологія: ценози трапляються у верхній частині Канівського та нижній Кременчуцького водосховищ і спорадично на Ірдинських болотах.
Асоціація Junco bufonii-Bidentetum connatae (табл. 2). Діагностичні види - Bidens connata, Juncus bufonius.

Ценотична характеристика: загальне проективне покриття травостою 80-100\%: B. connata 50-55\%, J. bufonius - 5-10\%. Флористичний склад вирізняється багатством і налічує 67 видів. Його формують переважно представники класу Bidentetea tripartitae, трапляються діагностичні види класів Alnetea glutinosae (Alnus glutinosa) і PhragmitoMagno-Caricetea (Lycopus europaeus). Кількість видів у описах 9-13.

Синекологія: угруповання приурочені до периферійних ділянок боліт (Ірдинські, Тясминські), вільшнякових лісів, що відзначаються постійним і змінним гідрорежимом упродовж вегетації з мулистими та торфовими грунтами. Частіше трапляються на знижених ділянках болотистих лук із сезонним поверхневим підтопленням (р. Ірдинка).

Синморфологія: угруповання двох'ярусні, їх утворюють види з широкою екологічною амплітудою. Перший ярус (10-20 м) формує Alnus glutinosa. Другий ярус утворений двома під’ярусами: перший (40-95 см) формують Bidens cernua, B. tripartita, B. connata, B. frondosa, Polygonum hydropiper, Carex acuta, Lycopus europaeus, Urtica dioica L., Cicuta virosa L., Butomus umbellatus L., Lythrum virgatum L., Equisetumpalustre L.; другий (10-45 см) - Ranunculus reptans L., Juncus bufonius, Glehoma hederacea L., Myosotis palustris L., Lysimachia nummularia L. Ценози поширені нерівномірно. Частіше трапляються рідко або спорадично.

Синдинаміка: угруповання започатковують сукцесійні ряди рослинності. Ценози змінюються угрупованнями лучної (Molinio-Arrhenatheretea), заплавнолісової (Alnetea glutinosae), болотної (Phragmito-Magno-Caricetea) або рудеральної (Stellarietea mediae, Plantagineta majoris) рослинності.

Синхорологія: угруповання поширені здебільшого у верхній частині Канівського та нижній частині Кременчуцького водосховищ. Розподілені переважно на лівому березі русла Дніпра, проте окремі осередки трапляються й на правому (Ірдинські болота).

Асоціація Bidentetum tripartitae (табл. 3); іiі діагностичні види - Bidens tripartita, Polygonum hydropiper i Potentilla anserina $\mathrm{L}$. 
Таблиця 1. Ценотична характеристика Bidentetum frondoso-connatae ass. nova hoc. loco

\begin{tabular}{|c|c|c|c|c|c|c|c|c|c|c|c|c|c|c|}
\hline Проективне покриття, \% & 100 & 80 & 60 & 55 & 60 & 70 & 80 & 70 & 70 & 80 & 70 & 45 & 60 & \multirow{4}{*}{ 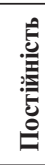 } \\
\hline Кількість видів & 13 & 12 & 10 & 9 & 12 & 12 & 11 & 11 & 11 & 8 & 11 & 9 & 10 & \\
\hline Номер опису авторський & 271 & 191 & 194 & 91 & 189 & 178 & 180 & 84 & 76 & 83 & 87 & 64 & 78 & \\
\hline Номер опису табличний & 1 & 2 & 3 & 4 & 5 & 6 & 7 & 8 & 9 & 10 & 11 & 12 & 13 & \\
\hline \multicolumn{15}{|c|}{ D. s. ass. Bidentetum frondoso-connatae } \\
\hline Bidens frondosa & 5 & 3 & 3 & 3 & 2 & 2 & 2 & 2 & 2 & 2 & 1 & 1 & $\mathrm{r}$ & V \\
\hline Bidens connata & 2 & 2 & 2 & $\mathrm{r}$ & 3 & 4 & 4 & 2 & 3 & 2 & 3 & 2 & 3 & V \\
\hline \multicolumn{15}{|c|}{ D. s. Bidention tripartitae $=$ Bidentetalia tripartitae $=$ Bidentetea tripartitae } \\
\hline Juncus bufonius & 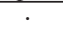 & 1 & & $\mathrm{r}$ & $\mathrm{r}$ & $\cdot$ & $\cdot$ & 1 & 1 & . & $\mathrm{r}$ & . & $\mathrm{r}$ & III \\
\hline Polygonum hydropiper & . & 2 & . & 2 & 1 & + & 1 & $\mathrm{r}$ & 2 & $\cdot$ & . & $\cdot$ & . & III \\
\hline Bidens cernua & . & $\cdot$ & · & . & 1 & . & . & . & $\mathrm{r}$ & . & . & . & . & I \\
\hline Bidens tripartita & . & . & $\cdot$ & $\cdot$ & . & . & $\cdot$ & . & $\cdot$ & $\cdot$ & . & $\cdot$ & $\mathrm{r}$ & I \\
\hline \multicolumn{15}{|c|}{ Інші види } \\
\hline Lycopus europaeus & 1 & . & 1 & 1 & $\mathrm{r}$ & . & . & $\mathrm{r}$ & . & 1 & . & 2 & $\mathrm{r}$ & IV \\
\hline Urtica dioica & . & $\mathrm{r}$ & $\cdot$ & 1 & $\cdot$ & $\mathrm{r}$ & $\mathrm{r}$ & $\cdot$ & 2 & $\cdot$ & $\mathrm{r}$ & $\cdot$ & $\mathrm{r}$ & III \\
\hline Carex acuta & . & . & . & . & . & 1 & 1 & $\cdot$ & 2 & . & . & 2 & 2 & II \\
\hline Alnus glutinosa & . & . & . & . & . & . & . & + & + & + & + & . & + & II \\
\hline Leersia oryzoides & . & . & . & 2 & . & 1 & . & 3 & $\cdot$ & 3 & $\cdot$ & . & . & II \\
\hline Thelypteris palustris & . & . & . & . & $\mathrm{r}$ & . & . & . & $\mathrm{r}$ & 2 & . & . & 1 & II \\
\hline Equisetum palustre & . & . & . & $\mathrm{r}$ & . & $\mathrm{r}$ & 1 & . & . & . & 1 & . & . & II \\
\hline Mentha aquatica & . & . & . & . & . & . & . & $\mathrm{r}$ & . & $\mathrm{r}$ & $\mathrm{r}$ & $\mathrm{r}$ & . & II \\
\hline Calystegia sepium & . & . & . & . & . & . & . & $\mathrm{r}$ & . & . & 3 & $\mathrm{r}$ & . & II \\
\hline Galium aparine & . & . & . & . & . & $\mathrm{r}$ & 2 & $\cdot$ & . & . & . & . & 1 & II \\
\hline Plantago major & . & 1 & . & . & 1 & . & . & . & . & . & . & 1 & . & II \\
\hline Cicuta virosa & . & . & . & . & . & · & . & $\mathrm{r}$ & $\mathrm{r}$ & . & . & . & $\mathrm{r}$ & II \\
\hline Chenopodium album & 1 & 1 & . & . & $\mathrm{r}$ & . & . & . & . & . & . & . & . & II \\
\hline Alisma plantago- aquatica & $\cdot$ & . & · & . & $\mathrm{r}$ & · & $\mathrm{r}$ & . & · & $\cdot$ & . & . & . & $\mathbf{I}$ \\
\hline Ranunculus repens & . & . & $\mathrm{r}$ & . & . & . & . & . & . & $\cdot$ & . & $\mathrm{r}$ & . & I \\
\hline Senecio vulgaris & . & . & . & . & . & . & 1 & $\mathrm{r}$ & . & . & . & . & . & I \\
\hline Solanum dulcamara & . & . & $\mathrm{r}$ & . & . & . & . & . & . & . & 2 & . & . & I \\
\hline Agrostis canina & . & 2 & 1 & . & . & · & . & $\cdot$ & . & . & . & . & . & I \\
\hline Lysimachia nummularia & . & . & . & . & . & $\mathrm{r}$ & 1 & . & . & . & . & . & . & I \\
\hline Xanthium albinum & $\mathrm{r}$ & . & . & . & . & . & . & . & . & $\cdot$ & . & . & . & $\mathbf{I}$ \\
\hline Polygonum persicaria & . & 1 & . & 1 & . & · & $\cdot$ & . & . & . & . & · & . & $\mathbf{I}$ \\
\hline Myosotis palustris & . & 1 & . & . & $\mathrm{r}$ & . & . & . & . & . & . & . & . & I \\
\hline Acer negundo & . & . & + & . & · & · & $\cdot$ & . & · & · & . & · & . & $\mathbf{I}$ \\
\hline Solanum nigrum & . & . & $\cdot$ & . & . & $\mathrm{r}$ & $\cdot$ & . & . & · & . & . & . & I \\
\hline Salix triandra & . & . & . & . & + & . & . & . & . & . & . & . & . & I \\
\hline Sagittaria sagittifolia & . & . & . & . & . & . & . & . & 1 & · & . & . & . & I \\
\hline Lythrum salicaria & $\mathrm{r}$ & . & . & . & . & . & . & . & . & . & . & . & . & I \\
\hline Epilobium palustre & $\cdot$ & . & . & $\mathrm{r}$ & . & . & . & . & . & . & . & $\cdot$ & . & I \\
\hline Phragmites australis & . & . & . & . & . & . & . & . & . & . & . & + & . & I \\
\hline Lysimachia vulgaris & . & . & $\mathrm{r}$ & . & . & . & . & . & . & . & . & $\cdot$ & . & I \\
\hline Typha latifolia & . & . & . & . & $\mathrm{r}$ & . & . & . & . & . & . & . & . & I \\
\hline Butomus umbellatus & & . & $\cdot$ & . & · & $\cdot$ & . & $\cdot$ & $\mathrm{r}$ & . & . & . & . & I \\
\hline Glechoma hederacea & . & . & . & . & . & 1 & . & . & . & . & . & . & . & I \\
\hline
\end{tabular}

П р и м і т к а. Крім того, поодиноко зазначені: Oenothera biennis (271), Daucus carota (271), Calamagrostis epigeios (271), Artemisia vulgaris (271), Erigeron canadensis (271), Equisetum sylvaticum (271), Verbascum phlomoides (271), Mentha spicata (191,194), Conium maculatum (180), Agrostis stolonifera (178), Stachys palustris (87), Lythrum virgatum (87), Rubus caesius (87), Vaccinium myrtillus (84), Urtica urens (83).

Місцезнаходження: 271 - Київська обл., Бориспільський р-н, с. Кийлов, прибережна ділянка р. Павлівка (27.08.2009); 191 - Київська обл., Бориспільський р-н, с. Проців, розорана ділянка біля штучного ставка (15.09.2006); 194 - Київська обл., Бориспільський р-н, с. Проців, окраїна заплавного лісу (15.09.2006); 91 - Полтавська обл., м. Кременчук, острів Уступ, регіональний ландшафтний парк «Кременчуцькі плавні» (23.08.2010); 189 Черкаська обл., Черкаський р-н, м. Черкаси, прибережна ділянка Кременчуцького водосховища (15.09.2006); 178 Київська обл., Бориспільський р-н, с. Проців, прибережна ділянка оз. Кошарище (15.09.2006); 180 - Черкаська обл., Золотоніський р-н, с. Дмитрівка, прибережна ділянка р. Супій (23.08.2008); 84 - Черкаська обл., Черкаський р-н, с. Свидівок, прибережна ділянка р. Ірдинка (17.09.2006); 76 - Полтавська обл., Кременчуцький р-н, с. Чечелеве, заплавний ліс (21.08.2010); 83 - Полтавська обл., м. Кременчук, острів Динька, регіональний ландшафтний парк «Кременчуцькі плавні» (23.08.2010); 87 - Полтавська обл., Кременчуцький р-н, заплава між селами Чечелеве та Маламівка (21.08.2010); 64 - Полтавська обл., м. Кременчук, острів Стрілецький, регіональний ландшафтний парк «Кременчуцькі плавні» (23.08.2010); 78 - Полтавська обл., Кременчуцький р-н, с. Маламівка, заплавна лука (21.08.2010). 
Таблиця 2. Ценотична характеристика Junco bufonii-Bidentetum connatae

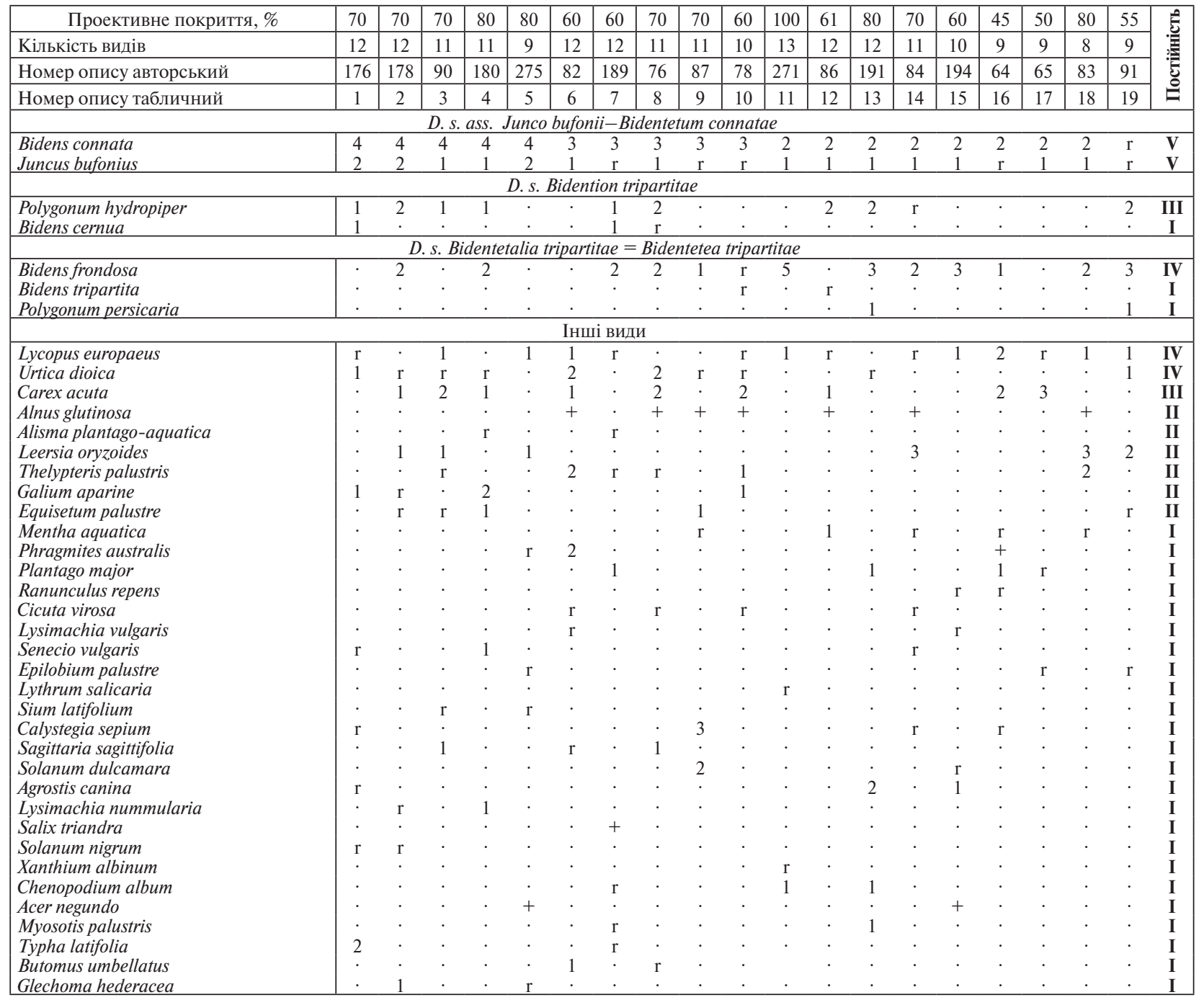

П р и м і т ка. Крім того, поодиноко зазначені: Oenothera biennis (271), Daucus carota (271), Calamagrostis epigeios (271), Artemisia vulgaris (271), Frangula alnus (275), Erigeron canadensis (271), Equisetum sylvaticum (271, 275), Verbascum phlomoides (271), Rorippa amphibia (194), Mentha spicata (191,194), Conium maculatum (180), Agrostis stolonifera (176,178), Scutellaria galericulata (90), Stachys palustris (87), Lythrum virgatum (87), Symphytum officinale (86), Rumex acetosella (86), Rubus caesius $(86,87)$, Ranunculus reptans (86), Eleocharis acicularis (86), Vaccinium myrtillus (84), Geum urbanum (82), Urtica urens (83), Salix caprea (65), Rumex acetosa (65), Quercus robur (65), Amorpha fruticosa (65).

Місцезнаходження: 176 - Київська обл., Бориспільський р-н, с. Проців, територія заплавного лісу (15.09.2006); 178 Київська обл., Бориспільський р-н, с. Проців, прибережна ділянка оз. Кошарище (15.09.2006); 90 - Полтавська обл., Кременчуцький р-н, заплавний ліс між селами Маламівка і Чечелеве (21.08.2010); 180 - Черкаська обл., Золотоніський р-н, с. Дмитрівка, прибережна ділянка р. Супій (23.08.2008); 275 - Київська обл., Бориспільський р-н, с. Проців, прибережна ділянка штучної водойми (27.08.2009); 82 - Полтавська обл., Кременчуцький р-н, с. Маламівка, заплавний ліс (21.08.2010); 189 - Черкаська обл., Черкаський р-н, м. Черкаси, прибережна ділянка Кременчуцького водосховища (15.09.2006); 76 Полтавська обл., Кременчуцький р-н, с. Чечелеве, заплавний ліс (21.08.2010); 87 - Полтавська обл., Кременчуцький р-н, заплава між с. Чечелеве та Маламівка (21.08.2010); 78 - Полтавська обл., Кременчуцький р-н, с. Маламівка, заплавна лука (21.08.2010); 271 - Київська обл., Бориспільський р-н, с. Кийлов, прибережна ділянка р. Павлівка (27.08.2009); 86 - Черкаська обл., Черкаський р-н, с. Будище, прибережна ділянка штучної водойми (17.09.2006); 191 - Київська обл., Бориспільський р-н, с. Проців, розорана ділянка біля штучного ставка (15.09.2006); 84 - Черкаська обл., Черкаський р-н, с. Свидівок, прибережна ділянка р. Ірдинка (17.09.2006); 194 - Київська обл., Бориспільський р-н, с. Проців, окраїна заплавного лісу біля штучної водойми (15.09.2006); 64 - Полтавська обл., м. Кременчук, острів Стрілецький, регіональний ландшафтний парк «Кременчуцькі плавні» (15.09.2006); 65 - Полтавська обл., м. Кременчук, острів Шаламай, регіональний ландшафтний парк «Кременчуцькі плавні» 23.08.2010); 83 - Полтавська обл., м. Кременчук, острів Динька, регіональний ландшафтний парк «Кременчуцькі плавні» (23.08.2010); 91 - Полтавська обл., м. Кременчук, острів Уступ, регіональний ландшафтний парк «Кременчуцькі плавні» (23.08.2010). 
Ценотична характеристика: загальне проективне покриття травостою 80-100 \%; Potentilla anserina 60-70\%, Bidens tripartita - 45-50\%, Polygonum hydropiper - 10-15\%. Флористичний склад відзначається багатством і налічує 68 видів. Його формують переважно представники класу Bidentetea tripartitae, трапляються також діагностичні види класу Salicetea purpureae (Salix triandra L.). Кількість видів у описах коливається в межах 10-15.

Синекологія: ценози приурочені до ділянок, які на початку весни повністю заливаються водою, а влітку - пересихають; грунти - мулисто-піщані, слабозадерновані, зрідка - піщані. Характерні для прибережних ділянок малих річок (Кропивна, Iрдинька, Павлівка, Ірклій), кар'єрів торфорозробок (Ірдинські та Тясминські болота), озер (Баклажанне, Кошарище), стариць, рукавів, ставків, берегів водосховищ, знижених ділянок болотистих лук із сезонним поверхневим підтопленням, заплавних лісів, знижених територій із синантропною рослинністю.

Синморфологія: угруповання двопід'ярусні, їх утворюють види з широкою екологічною амплітудою. Перший під'ярус (60-120 см) формують Bidens tripartita, B. frondosa, Polygonum hydropiper, Lycopus europaeus, Lythrum salicaria, Agrostis canina L., Leontodon autumnalis L., Filipendula ulmaria L; другий (10-45 см) - Potentilla anserina, Rorippa palustris, Lysimachia nummularia. Будова ценозів рівномірногрупова.

Синдинаміка: ценози започатковують сукцесійні ряди. Вони змінюються угрупованнями частіше рудеральної (Stellarietea mediae), рідше - лучної (Molinio-Arrhenatheretea) та болотної (PhragmitoMagno-Caricetea) рослинності.

Синхорологія: у долині Дніпра має середній ступінь поширення, основні масиви зосереджені на лівому березі, зокрема у верхній і нижній частинах Кременчуцького та Канівського водосховищ.

\section{Асоціація Bidenti tripartitae-Polygonetum} hydropiperis (табл. 4). Діагностичними видами є Bidens tripartita та Polygonum hydropiper.

Ценотична характеристика: загальне проективне покриття травостою - 80-100\%; Bidens tripartita - 20-30\%, P. hydropiper - 45-50\%. Флористичне багатство вирізняється найбільшою кількістю представників і налічує 91 вид. На відміну від усіх інших асоціацій, у ценозах значно більше видів синантропної та лучної рослинності. Для неї характерні насамперед представники класу Bidentetea tripartitae, трапляються також діагностичні види класів Phragmito-Magno-Caricetea (Stachys palustris), Salicetea purpureae (Salix triandra). Кількість видів у описах коливається в межах 11-18.

Синекологія: на відміну від попередніх ценози частіше займають площі, які відзначаються тривалим періодом затоплення протягом вегетації з мулистими, мулисто-піщаними та слабозадернованими грунтами. Трапляються на прибережних ділянках приток Дніпра (Вільшанка, Козинка, Бобриця, Горіхівка, Крива Руда), озер (Ситове, Баклажанне), штучних водойм, берегах водосховищ, територій із синантропною рослинністю (обабіч стежок, доріг, пустирів), на знижених ділянках болотистих лук зі змінним гідрорежимом.

Синморфологія: угруповання двопід'ярусні, їх утворюють види, що мають широку екологічну амплітуду. Перший під'ярус (50-100 см) представлений Bidens tripartita, B. frondosa, Polygonum hydropiper, Lycopus europaeus, Lythrum salicaria, Eupatorium cannabinum L. i Rumex confertus Willd. Другий (545 см) утворюють Plantago major, Potentilla anserina, Leersia oryzoides, Myosotis palustris, Rorippa palustris, Veronica anagallis-aquatica L., Lysimachia nummularia. За будовою ценози рівномірно-групові.

Синдинаміка: ценози започатковують сукцесійні ряди. Частіше вони змінюються угрупованнями лучної (Molinio-Arrhenatheretea), а також заплавно-лісової (Salicetea purpureae), рідше - болотної (Phragmito-Magno-Caricetea) та рудеральної (Stellarietea mediae) рослинності.

Синхорологія: найпоширеніша в долині, охоплює верхню, середню та нижню частини в основному лівих берегів Кременчуцького та Канівського водосховищ. Трапляється і на правому березі водосховищ, частіше на пониженнях.

Асоціація Bidentetum cernuae (табл. 5). Діагностичним видом є Bidens cernua.

Ценотична характеристика: загальне проективне покриття травостою 80-90(100) \%; Bidens cernua - 50-55 \%. Угруповання вирізняються багатством ценофлори, яка налічує 61 вид. Для неї характерні переважно представники класу Bidentetea tripartitae, трапляються також діагностичні види класу Phragmito-Magno-Caricetea (зокрема Stachys palustris і Lycopus europaeus). Кількість видів у описах коливається в межах 9-15.

Синекологія: ценози приурочені до ділянок із мулисто-піщаними грунтами, які повністю залиті водою протягом усього періоду вегетації. Трап- 
Таблиия. 3. Ценотична характеристика Bidentetum tripartitae

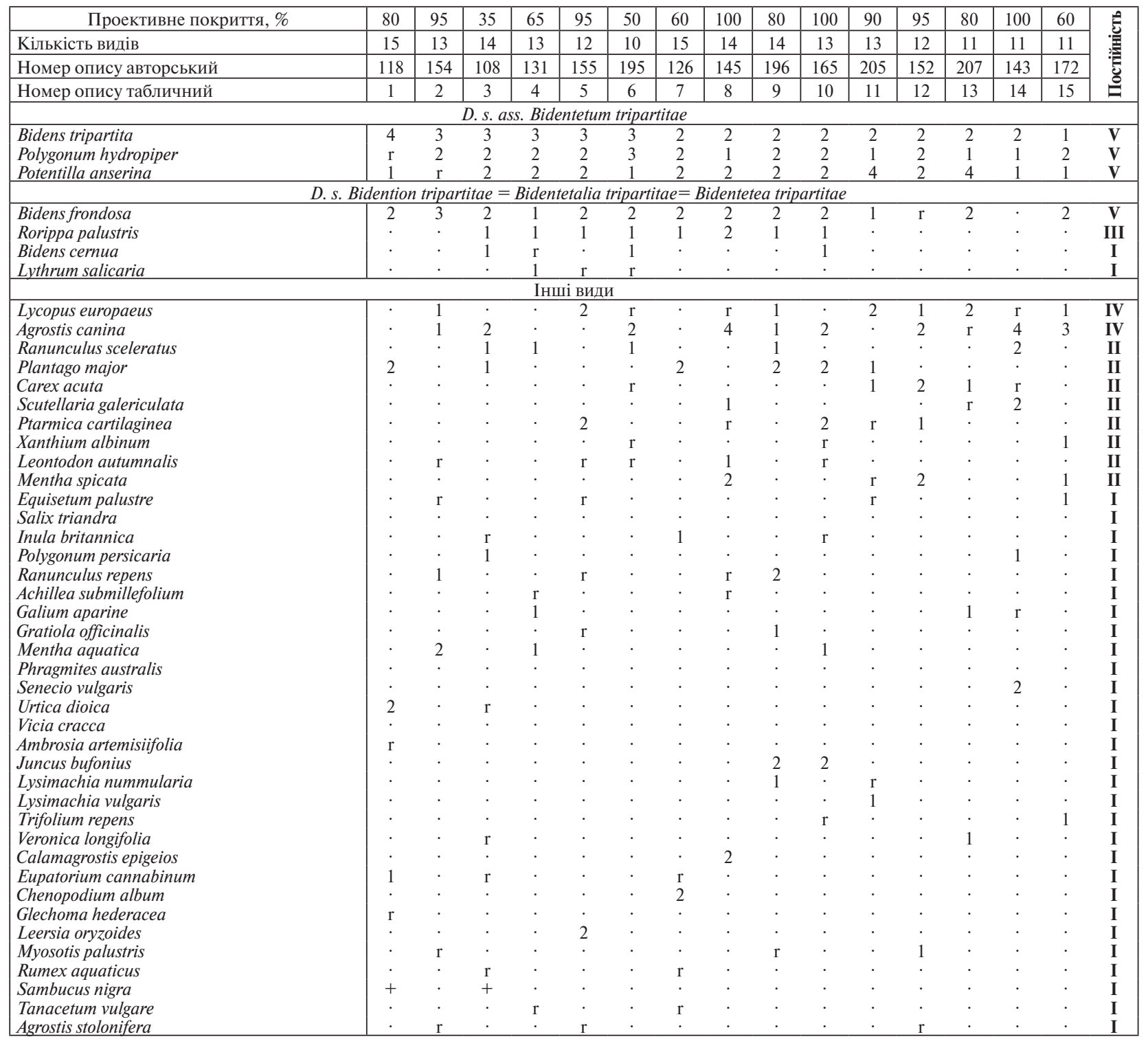

П р и м і т к а. Крім того, поодиноко відзначені: Veronica anagallis-aquatica (205), Potentilla erecta (195), Filipendula ulmaria (195), Campanula glomerata (195), Schoenoplectus lacustris (172), Odontites vulgaris (172), Cirsium setosum (131), Althaea officinalis (131), Tragopogon borystenicus (108), Echinochloa crus-galli (152), Capsella bursa-pastoris (126), Atriplex prostrata (126, 143), Polygonum aviculare (131), Juncus capitatus (207), Humulus lupulus (118), Arctium lappa (126), Setaria glauca (131), Verbascum phlomoides (118), Eleocharis acicularis (126, 145), Chelidonium majus (118), Alisma plantago-aquatica (196), Rumex acetosa (118), Epilobium palustre (118).

Місцезнаходження: 118 - Черкаська обл., Черкаський р-н, с. Будище, прибережна ділянка озера, що утворилося після торфорозробки (17.09.2005); 154 - Київська обл., Бориспільський р-н, с. Проців, р. Павлівка, заплавна лука (15.09.2006); 108 - Черкаська обл., Чигиринський р-н, с. Медведівка, долина р. Тясмин (11.08.2007); 131 - Черкаська обл., Черкаський р-н, с. Свидівок, прибережна ділянка р. Ірдинька (17.09.2006); 155 - Черкаська обл., Канівський р-н, с. Сушки, р. Горіхівка, заплавна лука (15.09.2006); 195 - Київська обл., Бориспільський р-н, с. Проців, прибережна ділянка оз. Кошарище (16.09.2006);126 - Черкаська обл., Чорнобаївський р-н, с. Іркліїв, прибережна ділянка р. Ірклій (17.09.2006); 145 - Черкаська обл., Золотоніський р-н, с. Кропивна, прибережна ділянка р. Кропивна (15.09.2006); 196Київська обл., Бориспільський р-н, с. Проців, прибережна ділянка оз. Чорненьке (16.09.2006); 165 - Київська обл., Переяслав-Хмельницький р-н, м. Переяслав-Хмельницький, долина р. Трубіж (15.09.2006); 205 - Київська обл., Бориспільський р-н, с. Проців, берегр. Павлівка (20.08.2008); 152 - Кіровоградська обл., Світловодський р-н, с. Велика Андрусівка, заплавна лука (15.09.2006); 207 - Київська обл., Бориспільський р-н, с. Проців, прибережна територія між р. Павлівка і оз. Кошарище (15.09.2006); 143 - Київська обл., Бориспільський р-н, с. Кийлов, р. Павлівка, заплавна лука (15.09.2006); 172 - Черкаська обл., Золотоніський р-н, с. Дмитрівка, заплавна лука р. Супій (15.09.2006). 
Таблиия 4. Ценотична характеристика Bidenti tripartitae-Polygonetum hydropiperis

\begin{tabular}{|c|c|c|c|c|c|c|c|c|c|c|c|c|c|c|c|c|c|c|}
\hline Проективне покриття, \% & 75 & 70 & 90 & 100 & 90 & 80 & 60 & 80 & 100 & 100 & 80 & 85 & 95 & 70 & 60 & 80 & 80 & \multirow{4}{*}{ 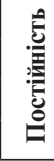 } \\
\hline Кількість видів & 17 & 14 & 14 & 17 & 15 & 14 & 13 & 13 & 18 & 17 & 16 & 13 & 13 & 11 & 17 & 17 & 16 & \\
\hline Номер опису авторський & 96 & 94 & 111 & 299 & 114 & 278 & 112 & 279 & 236 & 251 & 243 & 249 & 259 & 220 & 228 & 286 & 295 & \\
\hline Номер опису табличний & 1 & 2 & 3 & 4 & 5 & 6 & 7 & 8 & 9 & 10 & 11 & 12 & 13 & 14 & 15 & 16 & 17 & \\
\hline \multicolumn{19}{|c|}{ D. s. ass. Bidenti tripartitae-Polygonetum hydropiperis } \\
\hline Bidens tripartita & 3 & 3 & 3 & 2 & 2 & 2 & 2 & 2 & 1 & 1 & 1 & 1 & 1 & 1 & $\mathrm{r}$ & $\mathrm{r}$ & $\mathrm{r}$ & $\mathbf{V}$ \\
\hline Polygonum hydropiper & 2 & 2 & 2 & 1 & 2 & 2 & 2 & 2 & 4 & 2 & 2 & 3 & 3 & 2 & 2 & 2 & 2 & $\mathbf{V}$ \\
\hline Bidens cernua & 2 & 2 & 2 & . & 3 & . & 2 & . & $\cdot$ & . & . & . & . & . & . & . & . & II \\
\hline \multicolumn{19}{|c|}{ D. s. Bidentetalia tripartitae $=$ Bidentetea tripartitae } \\
\hline Bidens frondosa & 2 & 2 & 2 & 4 & $\mathrm{r}$ & 3 & 2 & 2 & 2 & $\cdot$ & 2 & 2 & 1 & 2 & 2 & 4 & $\mathrm{r}$ & $\mathbf{V}$ \\
\hline Rorippa palustris & . & . & 1 & . & . & . & . & . & . & . & . & . & . & 2 & . & . & 1 & I \\
\hline Carex acuta & 2 & 2 & . & 2 & . & . & · & . & . & . & . & . & 2 & . & 1 & 1 & 1 & III \\
\hline Xanthium albinum & . & . & . & $\mathrm{r}$ & $\mathrm{r}$ & . & . & . & $\mathrm{r}$ & . & $\mathrm{r}$ & $\mathrm{r}$ & . & . & . & . & $\mathrm{r}$ & II \\
\hline Potentilla anserina & 1 & . & 1 & $\mathrm{r}$ & . & . & . & 2 & 2 & $\mathrm{r}$ & . & . & . & . & . & . & . & II \\
\hline Phragmites australis & . & . & . & $\mathrm{r}$ & 1 & . & 1 & . & . & 2 & . & 1 & . & . & . & . & . & II \\
\hline Myosotis palustris & . & . & 1 & $\mathrm{r}$ & 1 & . & . & . & . & . & . & 1 & . & $\mathrm{r}$ & . & . & . & II \\
\hline Rumex aquaticus & 1 & 1 & . & $\mathrm{r}$ & . & . & . & . & . & $\mathrm{r}$ & . & . & . & $\mathrm{r}$ & . & . & . & II \\
\hline Eupatorium cannabinum & $\mathrm{r}$ & 1 & . & . & . & . & $\mathrm{r}$ & . & $\mathrm{r}$ & . & & . & . & . & . & . & . & II \\
\hline Urtica dioica & 1 & 1 & . & . & . & 1 & . & 2 & . & . & . & . & . & . & . & . & . & II \\
\hline Sonchus palustris & . & . & . & . & . & $\mathrm{r}$ & . & $\mathrm{r}$ & . & $\mathrm{r}$ & . & . & . & . & . & $\mathrm{r}$ & . & II \\
\hline Scutellaria galericulata & . & . & . & $\mathrm{r}$ & . & 2 & . & . & . & . & . & . & 1 & . & . & $\mathrm{r}$ & . & II \\
\hline Typha angustifolia & . & . & . & . & . & . & . & . & 2 & . & . & . & . & . & . & . & 3 & I \\
\hline Lysimachia vulgaris & $\mathrm{r}$ & $\cdot$ & . & . & . & . & . & . & $\mathrm{r}$ & $\mathrm{r}$ & . & . & . & . & . & . & . & I \\
\hline Polygonum aviculare & . & $\mathrm{r}$ & . & . & . & . & . & . & . & $\mathrm{r}$ & . & . & . & . & . & 1 & . & I \\
\hline Erigeron canadensis & . & . & . & 1 & . & . & . & . & . & . & . & . & . & . & 2 & $\mathrm{r}$ & . & I \\
\hline Oenothera biennis & $\mathrm{r}$ & . & . & . & $\mathrm{r}$ & . & . & . & . & . & . & $\mathrm{r}$ & . & . & . & . & . & I \\
\hline Stenactis аппиа & . & . & . & . & . & 2 & . & . & . & . & . & . & . & . & 1 & $\mathrm{r}$ & . & I \\
\hline Typha latifolia & . & . & . & . & . & . & . & . & . & . & . & . & . & . & . & $\mathrm{r}$ & 3 & I \\
\hline Amorpha fruticosa & . & $\mathrm{r}$ & . & . & . & . & . & . & . & + & . & . & . & . & . & . & . & I \\
\hline Agrostis canina & . & $\cdot$ & . & . & . & . & . & . & . & . & $\mathrm{r}$ & . & . & . & . & . & . & I \\
\hline Chenopodium album & . & . & . & . & . & . & . & . & $\mathrm{r}$ & . & . & . & . & . & 1 & . & . & $\mathbf{I}$ \\
\hline Leontodon autumnalis & . & . & . & . & . & . & . & . & . & . & . & . & 1 & . & . & . & $\mathrm{r}$ & I \\
\hline Ranunculus repens & . & . & . & . & . & . & . & . & . & $\mathrm{r}$ & . & . & $\mathrm{r}$ & . & . & . & . & I \\
\hline Calamagrostis epigeios & $\mathrm{r}$ & . & $\mathrm{r}$ & . & . & . & . & . & . & . & . & . & . & . & . & . & . & I \\
\hline Alisma plantago- aquatica & . & . & . & 2 & $\mathrm{r}$ & . & . & . & . & . & . & . & . & . & . & . & . & $\mathbf{I}$ \\
\hline Ptarmica cartilaginea & . & $\cdot$ & . & . & . & . & . & . & $\cdot$ & . & $\mathrm{r}$ & . & . & $\mathrm{r}$ & . & . & . & $\mathbf{I}$ \\
\hline Inula britannica & $\cdot$ & $\cdot$ & . & . & . & 1 & 1 & . & . & . & . & . & . & . & . & . & . & I \\
\hline Achillea submillefolium & . & . & . & . & . & $\mathrm{r}$ & . & . & $\mathrm{r}$ & . & . & . & . & . & . & . & . & $\mathbf{I}$ \\
\hline Artemisia vulgaris & . & . & . & . & . & . & . & . & $\mathrm{r}$ & . & $\mathrm{r}$ & . & . & . & . & . & . & I \\
\hline Lysimachia nummularia & . & $\cdot$ & . & . & . & 1 & . & 1 & $\cdot$ & . & . & . & . & . & . & . & . & $\mathbf{I}$ \\
\hline
\end{tabular}


Продовження таблиці 4

\begin{tabular}{|c|c|c|c|c|c|c|c|c|c|c|c|c|c|c|c|c|c|c|}
\hline Проективне покриття, \% & 75 & 70 & 90 & 100 & 90 & 80 & 60 & 80 & 100 & 100 & 80 & 85 & 95 & 70 & 60 & 80 & 80 & $\hat{\mathrm{E}}$ \\
\hline Кількість видів & 17 & 14 & 14 & 17 & 15 & 14 & 13 & 13 & 18 & 17 & 16 & 13 & 13 & 11 & 17 & 17 & 16 & 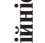 \\
\hline Номер опису авторський & 96 & 94 & 111 & 299 & 114 & 278 & 112 & 279 & 236 & 251 & 243 & 249 & 259 & 220 & 228 & 286 & 295 & 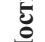 \\
\hline Номер опису табличний & 1 & 2 & 3 & 4 & 5 & 6 & 7 & 8 & 9 & 10 & 11 & 12 & 13 & 14 & 15 & 16 & 17 & \\
\hline Mentha aquatica & . & · & 1 & $\mathrm{r}$ & . & . & . & . & . & . & . & . & . & . & . & . & . & I \\
\hline Stachys palustris & · & $\cdot$ & · & · & - & · & 1 & · & · & · & · & $\mathrm{r}$ & · & $\cdot$ & . & · & · & I \\
\hline Taraxacum officinale & . & · & . & . & . & . & . & . & . & . & . & · & $\mathrm{r}$ & $\cdot$ & . & $\mathrm{r}$ & . & I \\
\hline Arctium lappa & . & · & . & . & . & . & . & . & . & . & . & . & . & · & . & $\mathrm{r}$ & . & I \\
\hline Ambrosia artemisiifolia & · & · & · & . & . & . & · & . & . & · & . & . & · & · & . & · & 1 & I \\
\hline Acer negundo & $\cdot$ & $\cdot$ & · & . & · & · & . & . & · & $\cdot$ & . & · & $\cdot$ & $\cdot$ & . & . & + & I \\
\hline Pоа аппиа & . & . & . & . & . & . & . & . & . & . & . & $\mathrm{r}$ & . & . & . & . & . & I \\
\hline Ranunculus acris & . & . & . & . & . & . & . & . & . & . & . & . & . & · & . & $\mathrm{r}$ & . & I \\
\hline Mentha spicata & . & . & . & . & 1 & . & . & . & . & . & . & . & . & · & . & . & . & I \\
\hline Salix triandra & . & . & · & . & . & · & . & . & + & . & . & . & · & $\cdot$ & . & · & . & I \\
\hline Urtica urens & . & . & $\cdot$ & . & $\cdot$ & $\cdot$ & $\cdot$ & $\cdot$ & $\mathrm{r}$ & . & . & . & $\cdot$ & $\cdot$ & $\cdot$ & . & $\cdot$ & $\mathbf{I}$ \\
\hline
\end{tabular}

П р и м і т к а. Крім того, поодиноко відзначені: Populus tremula (295), Acorus calamus (251, 259), Zizania aquatica (251, 259), Rumex thyrsiflorus (243), Potentilla argentea (236), Poa pratensis (228), Lemna minor (237), Daucus carota (228), Cichorium intybus (236), Veronica anagallis-aquatica (243), Filipendula ulmaria (279), Vicia cracca (228), Prunella vulgaris (278, 279), Galium palustre (278), Cirsium setosum (228), Equisetum arvense (228), Crepis ramosissima (228), Atriplex prostrata (228), Veronica longifolia (243), Juncus capitatus (243, 114), Carduus crispus (96), Berteroa incana (112), Humulus lupulus (94), Elytrigia repens (279), Peucedanum palustre (114), Glechoma hederacea (286), Agrostis stolonifera (112, 114), Symphytum officinale (96), Rumex acetosella (96, 114), Sagittaria sagittifolia (114), Galium aparine (279), Alnus glutinosa (279), Salix caprea (295).

Місцезнаходження: 96 - Черкаська обл., Черкаський р-н, с. Будище, прибережна ділянка озера, що утворилося після торфорозробки (22.08.2006); 94 - Черкаська обл., Черкаський р-н, с. Свидівок, прибережна ділянка р. Ірдинька (22.08.2006); 111 - Черкаська обл., Черкаський р-н, с. Будище, прибережна ділянка р. Ірдинька (22.08.2006); 299 Кіровоградська обл., Світловодський р-н, с. Павлівка, заплавналука (22.08.2011); 114-Черкаська обл., Черкаський р-н, с. Мошни, прибережна ділянка р. Вільшанка (22.08.2006); 278 - Київська обл., Бориспільський р-н, с. Проців, заплавна лука (27.09.2009); 112 - Черкаська обл., Черкаський р-н, с. Хацьки, долина р. Тясмин (22.08.2009); 279 - Київська обл., Бориспільський р-н, с. Проців, окраїна вільшняка (27.09.2009); 236 - Черкаська обл., м. Сміла, берег р. Тясмин (10.08.2008); 251 - Черкаська обл., Золотоніський р-н, с. Дмитрівка, прибережна ділянка р. Супій (23.08.2008); 243 - Київська обл., м. Київ, о. Муромець, узбережжя стариці (29.09.2010); 249 - Черкаська обл., Золотоніський р-н, с. Коробівка, заплава Кременчуцького водосховища (23.08.2008); 259 - Черкаська обл., Золотоніський р-н, с. Дмитрівка, прибережна ділянка р. Супій (23.08.2008); 220 - Київська обл., м. Київ, о. Муромець, узбережжя р. Десенка (18.09.2007); 228 - Київська обл., Бориспільський р-н, с. Вишеньки, берег оз. Баклажанне (18.08.2007); 286 - Кіровоградська обл., Світловодський р-н, с. Велика Скельова, Цибульська затока Кременчуцького водосховища (22.08.2011); 295 - Полтавська обл., м. Кременчук, о. Шаламай (22.08.2011).

Таблиця 5. Ценотична характеристика Bidentetum cernuae

\begin{tabular}{|c|c|c|c|c|c|c|c|c|c|c|c|c|c|c|c|c|}
\hline Проективне покриття, \% & 65 & 90 & 90 & 85 & 90 & 60 & 90 & 80 & 60 & 90 & 100 & 85 & 70 & 100 & 90 & \multirow{4}{*}{ 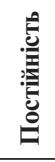 } \\
\hline Кількість видів & 11 & 15 & 15 & 14 & 14 & 13 & 11 & 10 & 10 & 9 & 15 & 15 & 14 & 14 & 14 & \\
\hline Номер опису авторський & 95 & 114 & 132 & 109 & 128 & 117 & 142 & 102 & 144 & 41 & 130 & 133 & 94 & 100 & 111 & \\
\hline Номер опису табличний & 1 & 2 & 3 & 4 & 5 & 6 & 7 & 8 & 9 & 10 & 11 & 12 & 13 & 14 & 15 & \\
\hline \multicolumn{17}{|c|}{ D. s. ass. Bidentetum cernuae } \\
\hline Bidens cernua & 4 & 3 & 3 & 3 & 3 & 3 & 3 & 3 & 3 & 3 & 2 & 2 & 2 & 2 & 2 & $\mathbf{V}$ \\
\hline \multicolumn{17}{|c|}{ D. $s$. Bidention tripartitae $=$ Bidentetalia tripartitae $=$ Bidentetea tripartitae } \\
\hline Bidens tripartita & 2 & 2 & $\cdot$ & $\cdot$ & 2 & $\cdot$ & 2 & 2 & $\mathrm{r}$ & 2 & 1 & 2 & 3 & 3 & 3 & $\mathbf{V}$ \\
\hline Polygonum hydropiper & . & 2 & 1 & 3 & . & 1 & 2 & . & . & 1 & 3 & 2 & 2 & . & 2 & IV \\
\hline Polygonum persicaria & . & . & 2 & . & . & . & 2 & . & 2 & . & 1 & . & . & . & · & II \\
\hline Bidens frondosa & 1 & $\mathrm{r}$ & 2 & 2 & 1 & 2 & $\cdot$ & 1 & . & 3 & 2 & 2 & 2 & 3 & 2 & $\mathbf{V}$ \\
\hline \multicolumn{17}{|c|}{ Інші види } \\
\hline Lycopus europaeus & $\cdot$ & $\mathrm{r}$ & 2 & 2 & 1 & . & $\cdot$ & 1 & $\mathrm{r}$ & $\mathrm{r}$ & 1 & $\cdot$ & $\cdot$ & 2 & $\mathrm{r}$ & IV \\
\hline Carex acuta & 1 & . & 2 & $\mathrm{r}$ & 3 & 1 & . & 2 & 2 & . & $\mathrm{r}$ & 2 & 2 & . & . & IV \\
\hline Plantago major & . & . & 1 & . & 1 & . & . & $\mathrm{r}$ & . & 1 & 2 & . & $\cdot$ & · & 1 & II \\
\hline Rumex aquaticus & $\cdot$ & . & $\cdot$ & $\mathrm{r}$ & . & $\mathrm{r}$ & . & $\mathrm{r}$ & . & . & . & . & 1 & $\mathrm{r}$ & . & II \\
\hline
\end{tabular}


Продовження таблиці 5

\begin{tabular}{|c|c|c|c|c|c|c|c|c|c|c|c|c|c|c|c|c|}
\hline Проективне покриття, \% & 65 & 90 & 90 & 85 & 90 & 60 & 90 & 80 & 60 & 90 & 100 & 85 & 70 & 100 & 90 & \\
\hline Кількість видів & 11 & 15 & 15 & 14 & 14 & 13 & 11 & 10 & 10 & 9 & 15 & 15 & 14 & 14 & 14 & 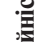 \\
\hline Номер опису авторський & 95 & 114 & 132 & 109 & 128 & 117 & 142 & 102 & 144 & 41 & 130 & 133 & 94 & 100 & 111 & ह \\
\hline Номер опису табличний & 1 & 2 & 3 & 4 & 5 & 6 & 7 & 8 & 9 & 10 & 11 & 12 & 13 & 14 & 15 & \\
\hline Phragmites australis & $\cdot$ & 1 & 2 & $\cdot$ & 2 & $\cdot$ & $\cdot$ & 1 & $\cdot$ & $\cdot$ & $\cdot$ & $\cdot$ & $\cdot$ & 1 & $\cdot$ & II \\
\hline Leersia oryzoides & $\cdot$ & 1 & 2 & . & . & . & . & $\cdot$ & . & . & . & 2 & 1 & . & 2 & II \\
\hline Lythrum salicaria & . & . & 1 & . & . & 2 & . & . & $\mathrm{r}$ & . & . & 2 & 1 & . & . & II \\
\hline Calamagrostis epigeios & $\cdot$ & $\cdot$ & $\cdot$ & . & · & $\mathrm{r}$ & . & 2 & $\cdot$ & $\cdot$ & · & $\cdot$ & · & $\mathrm{r}$ & $\mathrm{r}$ & II \\
\hline Eupatorium cannabinum & . & . & . & . & . & 1 & . & 1 & · & . & . & . & 1 & $\mathrm{r}$ & . & II \\
\hline Rorippa palustris & . & . & . & 1 & 1 & . & . & . & . & . & 2 & . & . & . & 1 & II \\
\hline Agrostis canina & $\cdot$ & $\cdot$ & . & . & . & . & 2 & $\cdot$ & 1 & 2 & 1 & . & . & . & $\cdot$ & II \\
\hline Humulus lupulus & . & . & . & . & $\mathrm{r}$ & 2 & . & . & . & . & . & $\mathrm{r}$ & $\mathrm{r}$ & . & . & II \\
\hline Potentilla anserina & . & . & . & . & . & . & $\mathrm{r}$ & . & 1 & . & 2 & . & . & . & 1 & II \\
\hline Myosotis palustris & . & 1 & . & 1 & . & . & . & . & · & . & $\mathrm{r}$ & . & . & . & 1 & II \\
\hline Eleocharis acicularis & . & . & . & 1 & 1 & . & $\mathrm{r}$ & . & $\mathrm{r}$ & . & . & . & . & . & . & II \\
\hline Urtica dioica & . & . & . & . & . & . & . & . & . & 1 & . & . & 1 & 2 & . & I \\
\hline Epilobium palustre & · & · & · & . & . & $\mathrm{r}$ & . & · & . & . & . & $\mathrm{r}$ & . & . & $\mathrm{r}$ & I \\
\hline Mentha aquatica & $\cdot$ & $\cdot$ & $\cdot$ & $\cdot$ & $\mathrm{r}$ & · & $\mathrm{r}$ & $\cdot$ & . & . & . & $\cdot$ & · & · & 1 & I \\
\hline Oenothera biennis & $\cdot$ & $\mathrm{r}$ & $\mathrm{r}$ & . & · & · & . & · & $\cdot$ & . & . & . & · & $\mathrm{r}$ & $\cdot$ & I \\
\hline Lysimachia vulgaris & . & . & . & . & . & . & $\mathrm{r}$ & . & $\mathrm{r}$ & . & . & . & . & $\mathrm{r}$ & . & $\mathbf{I}$ \\
\hline Alisma plantago- aquatica & $\cdot$ & $\mathrm{r}$ & $\cdot$ & 1 & $\mathrm{r}$ & $\cdot$ & $\cdot$ & $\cdot$ & · & $\cdot$ & $\cdot$ & $\cdot$ & · & $\cdot$ & $\cdot$ & $\mathbf{I}$ \\
\hline Agrostis stolonifera & $\cdot$ & 1 & . & $\mathrm{r}$ & $\mathrm{r}$ & . & . & . & . & · & . & $\cdot$ & . & $\cdot$ & $\cdot$ & $\mathbf{I}$ \\
\hline Calystegia sepium & 1 & . & . & $\mathrm{r}$ & . & . & . & . & . & . & . & 2 & . & . & . & I \\
\hline Sium latifolium & $\cdot$ & $\cdot$ & 1 & $\mathrm{r}$ & · & . & . & · & . & . & $\cdot$ & $\cdot$ & . & · & · & $\mathbf{I}$ \\
\hline Polygonum aviculare & . & . & . & . & . & . & . & . & . & . & 1 & . & $\mathrm{r}$ & . & . & I \\
\hline Arctium lappa & $\mathrm{r}$ & . & . & . & . & . & . & . & . & $\mathrm{r}$ & $\cdot$ & . & . & . & . & I \\
\hline Juncus bufonius & $\cdot$ & . & . & . & . & . & . & . & . & . & · & . & . & · & 1 & $\mathbf{I}$ \\
\hline Xanthium albinum & . & $\mathrm{r}$ & . & . & . & . & . & . & . & . & . & . & . & . & $\cdot$ & I \\
\hline Equisetum palustre & . & . & . & . & . & . & $\mathrm{r}$ & . & . & . & . & . & . & . & . & I \\
\hline Inula britannica & $\cdot$ & $\cdot$ & · & . & · & . & . & $\cdot$ & . & . & $\mathrm{r}$ & . & . & $\cdot$ & · & $\mathbf{I}$ \\
\hline Mentha spicata & · & 1 & $\cdot$ & . & . & . & . & . & . & · & . & . & . & $\cdot$ & . & $\mathbf{I}$ \\
\hline Ambrosia artemisiifolia & . & . & . & . & . & . & . & . & . & . & . & . & . & $\mathrm{r}$ & . & I \\
\hline Betula pendula & . & $\cdot$ & $\cdot$ & . & . & + & . & $\cdot$ & . & · & $\cdot$ & . & . & . & $\cdot$ & I \\
\hline Ranunculus sceleratus & $\cdot$ & $\cdot$ & 1 & · & · & · & . & · & · & . & $\cdot$ & . & . & · & . & I \\
\hline Rumex acetosella & . & 1 & . & . & . & . & . & . & . & . & . & . & . & . & . & I \\
\hline Sambucus nigra & $\cdot$ & . & . & . & . & + & . & . & . & . & . & . & . & . & . & I \\
\hline Solanum nigrum & . & . & . & . & . & . & . & $\cdot$ & . & . & . & . & $\mathrm{r}$ & . & . & I \\
\hline Stachys palustris & . & $\cdot$ & . & 1 & . & . & . & . & . & . & . & . & . & . & . & I \\
\hline
\end{tabular}

П р и м і т к а. Крім того, поодиноко відзначені: Crepis ramosissima (133), Chamerion angustifolium (133), Atriplex prostrata (142), Veronica longifolia (133), Typha angustifolia (100, 117), Juncus capitatus (114), Sonchus palustris (95), Artemisia vulgaris (95), Verbascum phlomoides (133), Peucedanum palustre (114), Glechoma hederacea (100), Acer negundo (130), Chelidonium majus (95), Senecio vulgaris (133), Sagittaria sagittifolia (114, 128), Urtica urens (95), Galium aparine (128), Amorpha fruticosa (94).

Місцезнаходження: 95 - Черкаська обл., Черкаський р-н, с. Будище, болотисті луки (22.08.2006); 114 - Черкаська обл., Черкаський р-н, с. Мошни, прибережна ділянка р. Вільшанка (22.08.2006); 132 - Черкаська обл., Черкаський р-н, с. Закревки, прибережна ділянка озера (22.08.2006); 109 - Черкаська обл., Черкаський р-н, с. Мошни, болотистий ліс (22.08.2006); 128 - Черкаська обл., Чигиринський р-н, с. Думанці, долина р. Тясмин (17.09.2006); 117 Черкаська обл., Черкаський р-н, с. Свидівок, болотиста лука (22.08.2006); 142 - Київська обл., Обухівський р-н, с. Козин, прибережна ділянка р. Козинка (15.09.2006); 102 - Черкаська обл., Черкаський р-н, с. Будище, прибережна ділянка р. Вільшанка (22.08.2006); 144 - Київська обл., Бориспільський р-н, с. Проців, знижена підтоплена ділянка луки біля оз. Чорненьке (15.09.2006); 41 - Черкаська обл., Золотоніський р-н, с. Кропивна, прибережна ділянка р. Кропивна (20.08.2010); 130 - Полтавська обл., Глобинський р-н, с. Проценки, прибережна ділянка р. Крива Руда (17.09.2006); 133 - Черкаська обл., Золотоніський р-н, с. Матвіївка, прибережна ділянка р. Супій (17.09.2006); 94 Черкаська обл., Черкаський р-н, с. Свидівок, прибережна ділянка р. Ірдинька (22.08.2006); 100 - Черкаська обл., Черкаський р-н, с. Будище, заплавна лука (22.08.2006); 111 - Черкаська обл., Черкаський р-н, с. Будище, прибережна ділянка р. Ірдинка (22.08.2006).

ISSN 0372-4123. Укр. ботан. журн., 2015, 72(4) 
ляються на прибережних ділянках приток (Супою, Золотоношки, Кропивної, Павлівки, Трубіжу, Ірклію, Горіхівки, Кривої Руди), струмків, штучних водойм, знижених ділянках болотистих лук.

Синморфологія: угруповання двопід'ярусні. Перший під'ярус $\quad(40-100$ см $)$ сформований Bidens cernua, B. tripartita, B. frondosa, Polygonum hydropiper, Lycopus europaeus, Lythrum salicaria, Carex acuta, Leersia oryzoides, Phragmites australis (Cav.) Steud., Eupatorium cannabinum, Rumex acetosella L., R. aquaticus L., Peucedanum palustre (L.) Moench. Дpyгий - (7-35см) утворюють Eleocharis acicularis (L.) Roem. \& Schult., Potentilla anserina, Juncus capitatus Weigel, Myosotis palustris. Ценози формують вузькі смуги або окремі осередки. Їхня будова групова.

Синдинаміка: угруповання започатковують сукцесійні ряди. Їх змінюють ценози лучної (MolinioArrhenatheretea), болотної (Phragmito-MagnoCaricetea) або рудеральної (Stellarietea mediae) рослинності.

Синхорологія: на досліджуваній території внаслідок надмірного антропогенного впливу угруповання має незначне поширення, трапляється переважно на лівому березі русла Дніпра, окремі осередки є й на правому березі (Ірдинські болота, заплава р. Тясмин).

Асоціація Bidenti frondosae-Atriplicetum prostratae (табл. 6). Діагностичні види Bidens frondosa, Atriplex prostrata DC.

Ценотична характеристика: загальне проективне покриття травостою 80-100\%; B. frondosa 55-60 \%, Atriplex prostrata 1-5\%. Флористичний склад налічує 54 види. Його формують переважно представники класу Bidentetea tripartitae, трапляються діагностичні види класу Phragmito-MagnoCaricetea (Lycopus europaeus). Кількість видів у описах коливається в межах 10-13.

Синекологія: угруповання приурочені до ділянок, які відзначаються змінним гідрорежимом протягом вегетації, добре витримують тривалу відсутність вологи, розвиваються на слабозадернованих грунтах. Характерні для прибережних ділянок малих річок (Козинка, Бобриця, Супій), озер (Баклажанне, Ситове), ставків, штучних водойм, берегів водосховища, меліоративних каналів, канав, рекреаційних ділянок (о-в Муромець), територій із синантропною рослинністю (узбіччя стежок, доріг, пустирі, околиці сіл).

Синморфологія: угруповання двопід'ярусні; їх формують види з широкою екологічною амплі- тудою. Перший під’ярус (80-150 см) утворюють Bidens tripartita, B. frondosa, Xanthium albinum (Widder) Scholz \& Sukopp, Inula britannica L., Chenopodium album, Ch. rubrum, Atriplex prostrata, Agrostis canina, Stenactis annua Nees, Erigeron canadensis L., Ptarmica cartilaginea Ledeb., Galium palustre L.; другий (1075 см) - Potentilla anserina, Rorippa palustris, Mentha spicata, Plantago major, Ranunculus reptans, R. acris L., Scutellaria galericulata L., Polygonum aviculare L. Цeнози утворюють суцільні зарості або розріджені смуги, розподілені рівномірно по всій території, особливо в місцях із надмірним антропогенним тиском.

Синдинаміка: ценози можуть змінюватися угрупованнями лучної (Molinio-Arrhenatheretea) pocлинності.

Синхорологія: розподілена рівномірно по всій території.

В асоціації Bidentetum frondoso-connatae високою вірністю відзначаються такі види: Bidens connata (phi - 58,5), Mentha spicata (phi - 30), B. frondosa (phi - 27,5); в Junco bufonii-Bidentetum connatae B. connata (phi - 58,5), Juncus bufonius (phi - 45,3), Cicuta virosa (phi - 39,9), Urtica dioica (phi - 39,8); B Bidentetum tripartitae - Leontodon autumnalis (phi - 35,6), B. tripartita (phi - 34,8), Filipendula vulgaris (phi - 28,4); в Bidenti tripartitae-Polygonetum hydropiperis - Plantago major (phi - 56,6), Veronica anagallis-aquatica (phi - 43,5), Rorippa palustris (phi - 40), Bidens tripartita (phi - 30,4), Polygonum hydropiper (phi - 25,4); в Bidentetum cernuae B. cernua (phi - 46,6), Eupatorium cannabinum (phi37,9), J. capitatus (phi - 29,3); Bidenti frondosaeAtriplicetum prostratae - Scutellaria galericulata (phi 56,5), Stenactis annua (phi - 46,6), Erigeron canadensis (phi - 44,1) (табл. 7).

\section{Висновки}

Угруповання Bidentetea tripartitae в долині Дніпра (в межах Лісостепу України) представлені шістьма асоціаціями, які належать до двох союзів, одного порядку та одного класу. Основними факторами, що визначають їхній розподіл у долині, є відмінності рельєфу, грунтового покриву та гідрологічного режиму.

Високою константністю характеризуються Bidens frondosa, B. tripartita, Polygonum hydropiper. Серед 138 видів, які сформували флористичне багатство класу Bidentetea tripartitae за відношенням до потреб у трофічних елементах грунту, найбіль-

ISSN 0372-4123. Ukr. Bot. J., 2015, 72(4) 
Таблиия 6. Ценотична характеристика Bidenti frondosae-Atriplicetum prostratae

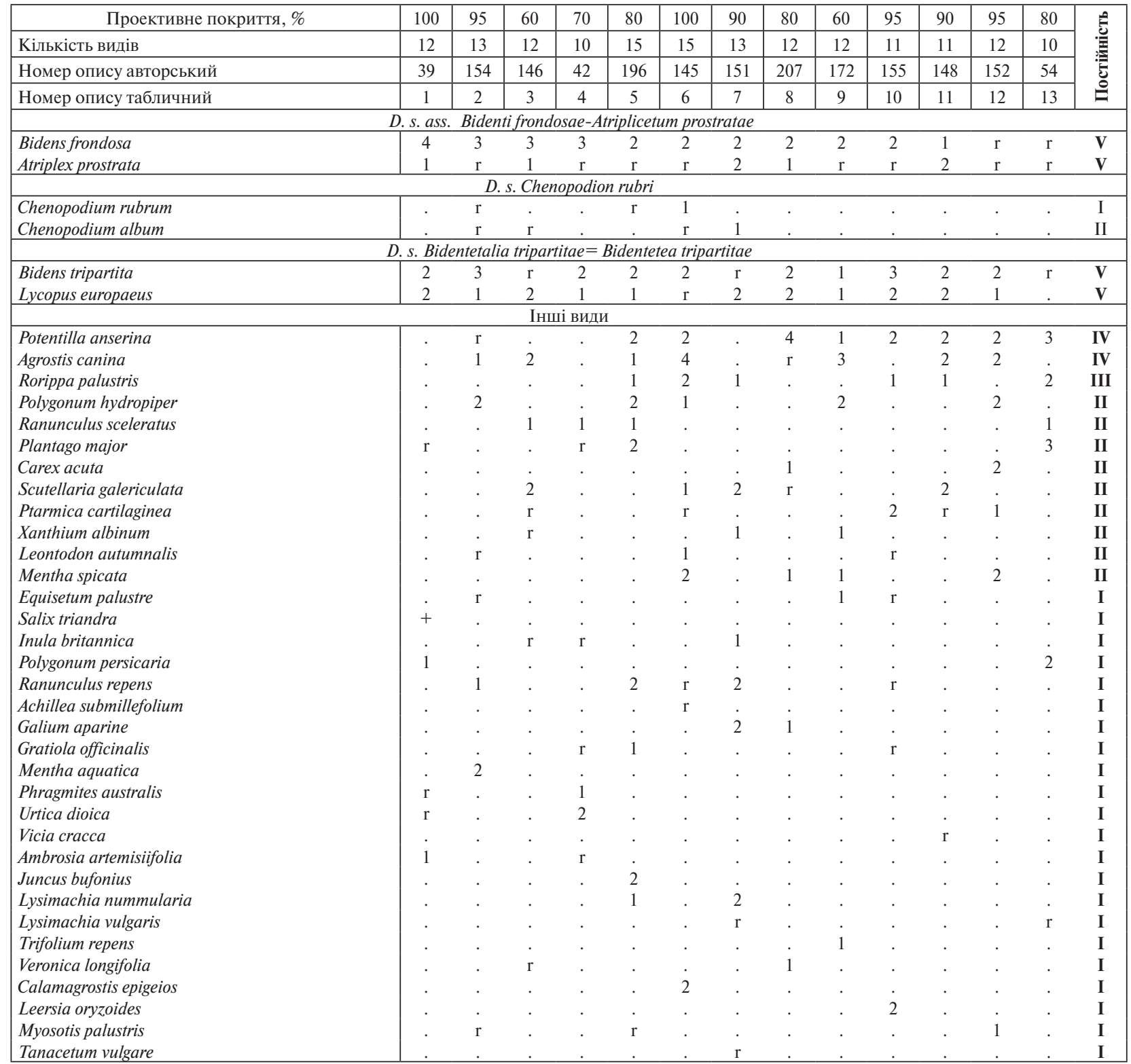

П р и м і т к а. Крім того, поодиноко зазначені: Schoenoplectus lacustris (172), Odontites vulgaris (172), Quercus robur (54), Polygonum amphibium (39), Pinus sylvestris (54), Echinochloa crus-galli (151, 152), Polygonum aviculare (54), Juncus capitatus (207), Arctium lappa (39), Oenothera biennis (146), Erigeron canadensis (146, 148), Acer negundo (148), Eleocharis acicularis (145), Alisma plantago-aquatica (196), Lythrum salicaria (39).

Місцезростання: 39 - Черкаська обл., Золотоніський р-н, с. Кропивна, прибережна ділянка р. Кропивна 3 синантропною рослинністю (20.08.2010); 154 - Київська обл., Бориспільський р-н, с. Проців, заплавна лука (15. 09.2006); 146 - Київська обл., Бориспільський р-н, с. Проців, прибережна порушена ділянка штучної водойми (15. 09.2006); 42 - Черкаська обл., Золотоніський р-н, с. Коробівка, прибережна ділянка 3 синантропною рослинністю (20.08.2010); 196 - Київська обл., Бориспільський р-н, с. Проців, прибережна ділянка оз. Чорненьке (16.09.2006); 145 - Черкаська обл., Золотоніський р-н, с. Кропивна, прибережна ділянка р. Кропивна (15.09.2006); 151 Київська обл., Бориспільський р-н, с. Проців, прибережна ділянка штучно створеного ставка (18.09.2006); 207 -

Київська обл., Бориспільський р-н, с. Проців, прибережна територія між р. Павлівка і оз. Кошарище (15.09.2006); 172 - Черкаська обл., Золотоніський р-н, с. Дмитрівка, заплавна лука р. Супій (15.09.2006); 155- Черкаська обл., Канівський р-н, с. Сушки, р. Горіхівка, заплавна лука (15.09.2006); 148 - Київська обл., Бориспільський р-н, с. Проців, ділянка з синантропною рослинністю (17.09.2006); 152 - Кіровоградська обл., Світловодський р-н, с. Велика Андрусівка, заплавна лука (15.09.2006); 52 - Полтавська обл., м. Кременчук, острів Фантазія, регіональний ландшафтний парк «Кременчуцькі плавні» (23.08.2010). 
Таблиия 7. Синоптична таблиця союзів асоціацій класу Bidentetea tripartitae долини Дніпра (в межах Лісостепу України) (на основі коефіцієнта рhі)

\begin{tabular}{|c|c|c|c|c|c|c|}
\hline Номер синтаксону & 1 & 2 & 3 & 4 & 5 & 6 \\
\hline Кількість описів & 16 & 20 & 21 & 21 & 20 & 12 \\
\hline \multicolumn{7}{|c|}{ Bidentetum frondoso-connatae } \\
\hline Bidens connata & 58,5 & 41,5 & - & - & - & - \\
\hline Chenopodium album & 35 & - & - & - & - & 11,8 \\
\hline Mentha spicata & 30 & - & 3,6 & - & 4,4 & - \\
\hline Bidens frondosa & 27,5 & - & 6,7 & 6,7 & - & 24,1 \\
\hline Equisetum sylvaticum & 25,5 & 5,5 & - & - & - & - \\
\hline \multicolumn{7}{|c|}{ Junco bufonii-Bidentetum connatae } \\
\hline Juncus bufonius & 17,3 & 45,3 & - & 2,7 & - & - \\
\hline Cicuta virosa & 9,4 & 39,9 & - & - & - & - \\
\hline Urtica dioica & - & 39,8 & 8,5 & - & - & - \\
\hline Alnus glutinosa & 23,2 & 34,7 & - & - & - & - \\
\hline Carex acuta & - & 30,4 & - & - & 25,7 & 11,9 \\
\hline Butomus umbellatus & - & 29,1 & - & - & 4,2 & - \\
\hline Lythrum virgatum & - & 29,1 & - & - & - & - \\
\hline Equisetum palustre & - & 28,3 & 13,6 & - & - & 4,3 \\
\hline \multicolumn{7}{|c|}{ Bidentetum tripartitae } \\
\hline Leontodon autumnalis & - & - & 35,6 & 7,7 & - & - \\
\hline Bidens tripartita & - & - & 34,8 & 30,4 & 16,4 & 19,4 \\
\hline Filipendula ulmaria & - & - & 28,4 & - & - & - \\
\hline Potentilla anserina & - & - & 25,1 & 29,7 & - & 10,1 \\
\hline \multicolumn{7}{|c|}{ Bidenti tripartitae-Polygonetum hydropiperis } \\
\hline Plantago major & - & - & 8,5 & 56,6 & - & - \\
\hline Veronica anagallis-aquatica & 0,9 & - & - & 43,5 & - & - \\
\hline Rorippa palustris & - & - & 15 & 40 & - & - \\
\hline Polygonum hydropiper & - & - & - & 25,4 & 4,9 & 4,9 \\
\hline \multicolumn{7}{|c|}{ Bidentetum cernuae } \\
\hline Bidens cernua & - & - & - & 4 & 46,6 & - \\
\hline Eupatorium cannabinum & - & - & 6,7 & - & 37,9 & - \\
\hline Juncus capitatus & - & - & - & 3,7 & 29,3 & - \\
\hline Rumex acetosella & - & 4,2 & - & - & 29,1 & - \\
\hline Peucedanum palustre & - & - & - & - & 29,1 & - \\
\hline Lythrum salicaria & - & - & - & - & 27,2 & 18,5 \\
\hline Rumex aquaticus & - & - & 4,5 & 4,5 & 26,8 & - \\
\hline \multicolumn{7}{|c|}{ Bidenti frondosae-Atriplicetum prostratae } \\
\hline Scutellaria galericulata & - & - & - & - & - & 56,5 \\
\hline Stenactis аппиа & - & - & - & - & - & 46,6 \\
\hline Erigeron canadensis & 11,3 & - & - & - & - & 44,1 \\
\hline Inula britannica & - & - & - & 14,8 & - & 40,8 \\
\hline Ptarmica cartilaginea & - & - & 4,9 & 10,8 & - & 33,1 \\
\hline Atriplex prostrata & - & - & 11,3 & 4,5 & - & 31,6 \\
\hline Xanthium albinum & - & - & - & 11,4 & - & 29,2 \\
\hline Polygonum aviculare & - & - & - & 21,2 & - & 27,5 \\
\hline Galium palustris & - & - & - & - & - & 26,5 \\
\hline Ranunculus acris & - & - & - & - & - & 26,5 \\
\hline
\end{tabular}

П р и м і т к а: Номерами позначені асоціації: 1 - Bidentetum frondoso-connatae, 2 - Junco bufonii-Bidentetum connatae, 3 - Bidentetum tripartitae, 4 - Bidenti tripartitae-Polygonetum hydropiperis, 5 - Bidentetum cernuae, 6 - Bidenti frondosaeAtriplicetum prostratae. 
ша кількість гемікарбонатофобів (62 \%), що належать до плюризональної (30 \%) та циркумполярної (33\%) хорологічних груп і $є$ індиферентними (80 \%) за градієнтом океанічності-континентальності. Поодиноко трапляються перацидофіли (1\%), семіоліготрофи (1\%) і мезофіли (1\%), які належать до аркто-меридіональної (1 \%), борео-температної (1\%) і євро-західносибірської $(1,5 \%)$ хорологічних груп. Найменше за градієнтом океанічності-континентальності представлені евконтинентальні групи (5\%).

Проведені дослідження вказують на необхідність з'ясування синтаксономії інших угруповань класів, представлених однорічниками, для визначення їхньої ролі в новоутворених екосистемах, зокрема штучних водосховищах. На це й будуть спрямовані наші подальші дослідження.

\section{СПИСОК ЛІТЕРАТУРИ:}

Barkman Ia. Ia. Botan. zhurn., 1989, 74(11), pp. 15451551. [Баркман Я.Я. Современные представления о непрерывности и дискретности растительного покрова и природе растительных сообществ в фитосоциологической школе Браун-Бланке // Ботан. журн. -1989. - 74(11). - С. 1545-1551.]

Braun-Blanquet J. Pflanzensociologie, Wien, New-York: Springer-Verlag, 1964. - $865 \mathrm{~s}$.

Didukh Ya.P. The ecological scales for the species of Ukrainian flora and their use in synphytoindication, Kyiv: Phytosociocentre, 2011, $176 \mathrm{p}$.

Dubyna D.V., Dvoretskyi T.V., Dziuba T.P., Zhmud O.I., Tymoshenko P.A. Ukr. fitotsenolohichnyi zbirnyk, Ser. A, vyp. 18, Kyiv, 2002, pp. 110-115 [Дубина Д.В., Дворецький Т.В., Дзюба Т.П., Жмуд О.І., Тимошенко П.А. Синантропна рослинність дельти Кілійського гирла Дунаю // Укр. фітоценолог. зб. Сер. А. - К., 2002. - Вип. 18. - С. 110-115.]

Hennekens S.M., Schaminée J.H.J. TURBOVEG, a comprehensive data base management system for vegetation data, J. Veget. Sci., 2001, 12, pp. 589-591.

Ishbirdin A.R., Ishmuratova M.M., Zhirnova T.V. Vestnik Nizhegorod. un-ta, Ser. Biologiia, Nizhnii Novgorod:
Izd-vo Nizhegorod. gos. un-ta im. N.I. Lobachevskogo, 2005, 1, pp. 85-98. [Ишбирдин А.Р., Ишмуратова М.М., Жирнова Т.В. Стратегии жизни ценопопуляции Cephalanthera rubra (L.) Rich. на территории Башкирского государственного заповедника // Вестн. Нижегород. ун-та им. Н.И. Лобачевского. Сер. Биол. - Нижний Новгород: Изд-во Нижегород. гос. ун-та им. Н.И. Лобачевского, 2005. - 1. - С. 85-98.] Levon A.F. Ukr. fitotsenolohichnyi zbirnyk, Ser. A, vyp. 3, Kyiv, 1996, pp. 104-107 [Левон А. Ф. Синтаксономия рудеральной растительности Ялты. III класс $B i-$ dentetea tripartite // Укр. фітоценол. зб. Сер. А. - К., 1996. - Вип. 3. - С. 104-107.]

Mirkin B.M., Naumova L.G., Solomeshch A.I. Sovremennaia nauka o rastitelnosti (Modern Vegetation Science), Moscow: Logos, 2002, 262 р. [Миркин Б.М, Наумова Л.Г., Соломещ А.И. Современная наука о растительности: учебник. - М.: Логос, 2002. - 262 с.]

Opredelitel vysshikh rasteniy Ukrainy, Kyiv: Phytosociocentre, 1999, 545 р. [Определитель высших растений Украины / Д.Н. Доброчаева, М.И. Котов, Ю.Н. Прокудин [и др.]. - К.: Фітосоціоцентр, 1999. - 545 с.]

Osypenko V.V., Shevchyk V.L., Ukr. fitotsenolohichnyi zbirnyk, Ser. A, Kyiv, 2001, vyp. 17, pp. 104-122 [Осипенко В.В., Шевчик В.Л. Спонтанна рослинність м. Черкаси. 6. Рудеральна рослинність прибережної частини м. Черкаси // Укр. фітоценолог. зб. Сер. А. К., 2001. - Вип. 17. - С. 104-122.]

Sypailova L.M., Sheliah-Sosonko Yu.R. Ukr. fitotsenolohichnyi zbirnyk. Ser. A., Kyiv, 1996, vyp. 1, pp. 28-40. [Сипайлова Л.М., Шеляг-Сосонко Ю.Р. Лучна рослинність заплав річок рівнинної частини України // Укр. фітоценолог. зб. Сер. А. - К., 1996. - Вип. 1. - C. 28-40.]

Tichý L. JUICE, software for vegetation classification, J. Veget. Sci., 2002, 13, pp. 451-453.

Weber H.E., Moravec J., Theurillat J.-P. International Code of Phytosociological Nomenclature. 3rd edition, J. Veget. Sci., 2000, 11, pp. 739-768.

Willner W., Tichý L., Chytrý M. Effects of different fidelity measures and contexts on the determination of diagnostic species, J. Veget. Sci., 2009, 20, pp. 130-137.

Рекомендує до друку

Надійшла 15.06.2015 p.

Я.П. Дідух 
Махиня Л.М. Синтаксономия класса Bidentetea tripartitae долины Днепра (в пределах Лесостепи Украины). - Укр. ботан. журн. - 2015. - 72(4): 310-324.

Национальный медицинский университет имени А. А.Богомольца

ул. Пушкинская, 22, г. Киев, 01601, Украина

В статье приведена синтаксономия класса Bidentetea tripartitae Tüxen et al. ex von Rochow 1951 долины Днепра, которая включает шесть ассоциаций, относящихся к одному порядку (Bidentetalia tripartitae Br.-Bl. et R. Tx. ex Klika et Hadač 1944) и двум союзам (Bidention tripartitae Nordhagen ex Klika et Hadač 1940, Chenopodion rubri (Tüxen 1960) Hilbig et Jage 1972). Основными факторами, определяющими их распределение в пойме, являются отличия рельефа, почвенного покрова и гидрологического режима. Ценофлора класса насчитывает 138 видов, которые принадлежат к 105 родам и 43 семействам. Диагностические виды класса - Lythrum salicaria L., Rorippa palustris (L.) Besser, B. cernua L., B. frondosa L., B. tripartita L., Polygonum hydropiper L., P. persicaria L. Высокой константностью отличаются $B$. frondosa, $B$. tripartita и $P$. hydropiper. Средний уровень константности характерен для B. cernua, B. connata Muhl. ex Willd. и Juncus bufonius L. Низкий - присущий Myosoton aquaticum (L.) Moench и диагностическим видам других классов, в частности Potentilla anserina L. (Plantaginetea majoris), Lycopus europaeus L. (Phragmito-Magno-Caricetea), Agrostis canina L. (Molinio-Arrhenatheretea) и Atriplex prostrata DC. (Stellarietea mediae).

К л ю ч е в ы е с л о в а: синтаксономия, экологоценотическая характеристика, прибрежно-водная растительность, долина Днепра, Bidentetea tripartitae
Makhynya L.M. The syntaxonomy of the class Bidentetea tripartitae of the Dnipro River valley (within Forest-Steppe of Ukraine). - Ukr. Bot. J. - 2015. - 72(4): 310-324.

O.O. Bogomolets National Medical University

22, Pushkinska Str., Kyiv, 01601, Ukraine

The article describes syntaxonomy of the class Bidentetea tripartitae Tüxen et al. ex von Rochow 1951 in the valley of the Dnipro River, which includes six associations of one order, Bidentetalia tripartitae Br.-Bl. et R. Tx. ex Klika et Hadač 1944, and two unions, Bidention tripartitae Nordhagen ex Klika et Hadač 1940 and Chenopodion rubri (Tüxen 1960) Hilbig et Jage 1972. The main factors determining their distribution within the valley are differences in relief, soil and hydrological regime. Cenoflora of the class includes 138 species that belong to 105 genera and 43 families. Diagnostic species of the class are: Lythrum salicaria L., Rorippa palustris (L.) Besser, Bidens cernua L., B. frondosa L., B. tripartita L., Polygonum hydropiper L., and P. persicaria L. High constancy is specific to species Bidens frondosa, B. tripartita, and Polygonum hydropiper. Its average level is typical for the species $B$. cernua, $B$. connata Muhl. ex Willd. and Juncus bufonius L. Low level is characteristic for Myosoton aquaticum (L.) Moench and diagnostic species of other classes, in particular Potentilla anserina (Plantaginetea majoris), Lycopus europaeus L. (Phragmito-MagnoSaricetea), Agrostis canina L. (Molinio-Arrhenatheretea), Atriplex prostrata DC. (Stellarietea mediae).

K e y w o r d s: syntaxonomy, ecological-coenotic characteristic, coastal-aquatic vegetation, valley of the Dnipro River, Bidentetea tripartitae

\section{НОВІ ВИДАННЯ}

Чопик В.І., Федорончук М.М. Флора Украӥнських Kapnam. - Тернопіль: ТзОВ «Тернограф», 2015. - 712 с.

«Флора Українських Карпат»є повним зведенням видового складу судинних рослин цієї території, що за суттю і формою можна розглядати як друге видання «Визначника рослин Українських Карпат» (1977). Новим у цій праці є збільшення видового складу на 520 таксономічних найменувань. Таким чином, флора Українських Карпат нараховує 2532 види спонтанної флори, а також найбільш важливі культивовані види. Наведено їхню географічну, екологічну, фітосозологічну характеристики та сучасну номенклатуру. Подається латинська абетка, а також транслітерація українських і латинських вимовлень. Це важливо, оскільки нині у вишах не викладають основи латинської мови, і студенти вимовляють латинські назви на англійський манер, що утруднює розуміння, про яку саме рослину йдеться. Вперше в українській і колишній союзній (за деякими винятками) науковій ботанічній літературі подано наголоси на назвах усіх таксонів, що уніфікує та стандартизує їх з європейськими мовами. Необхідність видання «Флори ...» на сучасному рівні диктується ще й тим, що наявні сьогодні «Флора України» (1937- 1964), російськомовний «Определитель высших растений Украины» (1987), «Визначник рослин Українських Карпат» (1977) фахово та морально застаріли і стали бібліографічними раритетами. Праця ілюстрована габітуальними й аналітичними малюнками.

Для науковців (систематиків, флористів, екологів, спеціалістів з охорони природи), працівників лісового та сільського господарств, викладачів вишів, фармацевтів, туристів, студентів біологічних, сільськогосподарських і лісівничих спеціальностей. 